\title{
Productive and Reproductive Performance of Heifers Fed Different Levels of Urea in the Diet $^{1}$
}

\author{
Desempenho Produtivo e Reprodutivo de Novilhas Alimentadas com Diferentes \\ Níveis de Uréia na Dieta
}

\author{
Alessandra Silva ${ }^{2 *}$, José Neuman Miranda Neiva ${ }^{3 *}$, Vera Lucia Araujo ${ }^{3}$, Alencariano Jose Silva Falcão ${ }^{3}$ e Álan \\ Maia Borges ${ }^{4}$
}

\begin{abstract}
The objective of the present study was to evaluate the nutrient intake, blood parameters, follicular diameter and performance of pre-puberty crossbred heifers fed isoproteic diets $(14.1 \% \mathrm{CP})$ containing $0.0 ; 0.44 ; 0.88$ and $1.32 \%$ urea on the total dry matter (DM) of the diet, with a 77:23 roughage:concentrate ratio. Twenty-four 18- month old heifers (Holstein x Zebu), $277.9 \mathrm{~kg}$ mean live weight (LW) were used, distributed in four treatments and six replications in a randomized complete design. The following were evaluated: dry matter intake (DM), crude protein (CP), neutral detergent fiber (NDF), acid detergent fiber (ADF), ether extract (EE), hemicellulose (HEM), plasmatic ureic nitrogen (PUN), plasmatic glucose, plasmatic total cholesterol, follicular diameter and daily weight gain (DWG). No influence of the urea levels in the diet was observed on NDF and HEM intake. A maximum intake was obtained of DM $\left(8.75 \mathrm{~kg} \mathrm{day}^{-1}\right), \mathrm{CP}\left(0.88 \mathrm{~kg} \mathrm{day}^{-1}\right), \operatorname{ADF}\left(2.5 \mathrm{~kg} \mathrm{day}^{-1}\right)$ and $\mathrm{EE}\left(0.17 \mathrm{~kg} \mathrm{day}^{-1}\right)$ respectively for the levels $0.7,0.8,0.7$ and $0.7 \%$ urea in total $\mathrm{DM}$. The $0.6 \% ; 0.77 \%$ and $0.6 \%$ urea levels in diet were the critical points for obtaining maximum response for the PUN $\left(10.96 \mathrm{mg} \mathrm{dL}^{-1}\right)$ and plasmatic glucose (84.97 $\left.\mathrm{mg} \mathrm{dL}^{-1}\right)$ concentrations and, for follicular diameter $(11.08 \mathrm{~mm})$ on the $40^{\text {th }} ; 24^{\text {th }}$ and $31^{\text {st }}$ day, respectively. The plasmatic total cholesterol concentration and DWG were not influenced by the urea added to the diet, with averages of $119.39 \mathrm{mg} \mathrm{dL}^{-1}$ and $1.66 \mathrm{~kg} \mathrm{day}^{-1}$, respectively. It was concluded that urea can be added up to $1.32 \%$ on the total DM of the diet for pre-puberty crossbred heifers.
\end{abstract}

Key words - Cholesterol. Feedlot. Plasmatic ureic nitrogen. Weight gain.

Resumo - Com o presente trabalho objetivou-se avaliar o consumo de nutrientes, parâmetros sangüíneos, diâmetro folicular e desempenho de novilhas mestiças pré-púberes alimentadas com dietas isoprotéicas $(14,1 \% \mathrm{~PB})$ contendo 0,$0 ; 0,44 ; 0,88$ e $1,32 \%$ de uréia na matéria seca (MS) total, com relação volumoso:concentrado 77:23. Utilizaram-se vinte e quatro novilhas (Holandês x Zebu) com média de 277,9 kg de peso vivo (PV) e 18 meses de idade, distribuídas em quatro tratamentos e seis repetições em delineamento inteiramente casualizado. Foram avaliados consumos de matéria seca (MS), proteína bruta (PB), fibra em detergente neutro (FDN), fibra em detergente ácido (FDA), extrato etéreo (EE), hemicelulose (HEM), nitrogênio uréico plasmático (NUP), glicose plasmática, colesterol plasmático total, máximo diâmetro folicular e ganho de peso diário (GPD). Não foi observada influencia dos níveis de uréia na dieta sobre os consumos de FDN e HEM. Obteve-se o máximo consumo de $\mathrm{MS}\left(8,75 \mathrm{~kg} \mathrm{dia}^{-1}\right), \operatorname{PB}\left(0,88 \mathrm{~kg} \mathrm{dia}^{-1}\right)$, FDA $\left(2,5 \mathrm{~kg} \mathrm{dia}^{-1}\right)$ e EE $\left(0,17 \mathrm{~kg} \mathrm{dia}^{-1}\right)$ respectivamente para os níveis 0,7 ; 0,$8 ; 0,7$ e $0,7 \%$ de uréia na MS total da dieta. Os níveis $0,6 \% ; 0,77 \%$ e $0,6 \%$ de uréia na dieta foram os pontos críticos para obtenção de resposta máxima para as concentrações de NUP $\left(10,96 \mathrm{mg} \mathrm{dL}^{-1}\right)$ e glicose plasmática $\left(84,97 \mathrm{mg} \mathrm{dL}^{-1}\right)$ e, para o diâmetro folicular $(11,08 \mathrm{~mm})$ nos respectivos dias $40^{\circ} ; 24^{\circ}$ e $31^{\circ}$. A concentração do colesterol plasmático total e o GPD não foram influenciados pela adição de uréia, com médias de $119,39 \mathrm{mg} \mathrm{dL}^{-1}$ e 1,66 $\mathrm{kg} \mathrm{dia}^{-1}$, respectivamente. Conclui-se que a uréia pode ser adicionada até $1,32 \%$ na MS total da dieta para novilhas mestiças pré-púberes confinadas.

Palavras-chave - Colesterol. Confinamento. Ganho de peso. Nitrogênio ureico plasmático.

\footnotetext{
* Autor para correspondência

${ }^{1}$ Recebido para publicação em 13/03/2009; aprovado em 27/09/2010

Part of the dissertation of first author, Postgraduate Program in Tropical Animal Science of the UFT

${ }^{2}$ Programa de Pós-Graduação em Morfofisilogia Animal da FCAV, Universidade Estadual Paulista, alesilvavet@yahoo.com.br

${ }^{3}$ Escola de Medicina Veterinária e Zootecnia, Universidade Federal do Tocantins, araguaia2007@gmail.com, veraluciaaraujo@yahoo.com.br, alencariano@uft.edu.br

${ }^{4}$ Escola de Veterinária, Universidade Federal de Minas Gerais, alanmborges@vet.ufmg.br
} 


\section{Introduction}

Substituting true protein sources, such as soybean meal, with urea in feedlot steer diet has shown good results, giving food intake and weight gain similar to those obtained with true protein and in other cases it has generated efficient food conversion because it reduced food intake without affecting weight gain (MAGALHÃES et al., 2006; RENNÓ et al., 2005).

However, its use with females has presented contrary results. There is evidence of low fertility rates when high levels of rumen degradable protein are offered because it raises the circulating ammonia and urea concentrations resulting in an energy deficit (GARCIABOJALIL et al., 1998b). Both ammonia conversion to urea in the liver from the urea cycle and urea excretion by the kidneys, spend a lot of energy.

In a situation of energy deficit, the blood concentrations of glucose, insulin growth factor similar to insulin type 1 (IGF-I) decrease and reach levels incapable of stimulating production the gonadotropin-releasing hormone $(\mathrm{GnRH})$ and luteinizing hormone $(\mathrm{LH})$, leading to ovarian acyclicity that damages fertility (BOLAND et al., 2001; DISKIN et al., 2003).

The objective of the present study was to assess the effect of different urea levels in the diet on nutrient intake, blood parameters, ovarian activity and daily weight gain in pre-puberty crossbred heifers in a feedlot.

\section{Material and methods}

The experiment was carried out in the College of Veterinary Medicine and Animal Science at the Federal University of Tocantins, Araguaína Campus, TO, Brazil, from July to September 2007. Four diets were assessed containing $0 ; 0.44 ; 0.88$ and 1.32 urea included in the total dry matter (DM) (TAB. 1). The diets were formulated according to the NCR (2001) requirements to be isoproteic $(14.1 \% \mathrm{CP})$ with expected DM intake of $7.1 \mathrm{~kg} \mathrm{day}^{-1}$ to allow a daily weight gain of $0.75 \mathrm{~kg} \mathrm{animal}^{-1} \mathrm{day}^{-1}$. Sorghum silage was used with a 77:23 roughage:concentrate ratio based on the total DM.

Twenty-four 18-month old heifers (Holstein $\mathrm{x}$ Zebu) were used, $277.9 \mathrm{~kg}$ mean live weight, distributed in a randomized complete design for the four treatments with six replications and each replication consisted of one animal. The experimental period was 57 days, with seven days for adaptation and 50 days for data collection.

At the start of the adaptation period, the animals were wormed and housed individually in stalls with individual troughs and one drinking bowl for two animals. The diets were supplied at 9 am and $5 \mathrm{pm}$ with orts between 5 and $10 \%$ of the daily total offered. The food orts from the previous day were collected and weighed daily before the first feeding and samples of the orts of the foods offered were collected weekly and then grouped in two week periods.

The contents were determined in the food samples (offered and orts) of the dry matter (DM), crude protein (CP) and ether extract (EE) as described by Silva and Queiroz (2002). The analyses of neutral detergent fiber (NDF), acid detergent fiber (ADF) and hemicelluloses (HEM) were analyzed according to methodology by Van Soest et al. (1991). The chemical-bromatological analyses of these samples were carried out in the Animal Nutrition Laboratory at the UFMG Veterinary School, in Belo Horizonte, MG.

At the end of the adaptation period, the animals were weighed (initial weight), then every 14 days to follow the weight gain and at the end of the 50 days (final weight). The difference in final weight compared to the initial weight divided by the number of days in the feedlot was used to determine the daily weight gain.

The intakes of DM, CP, NDF, ADF, HEM and EE were assessed and expressed in kilogram per day $\left(\mathrm{kg} \mathrm{day}^{-1}\right)$ in grams per unit of metabolic size $\left(\mathrm{g} \mathrm{kg}^{-1} \mathrm{LW}^{0.75}\right)$, percentage of live weight $(\% \mathrm{LW})$ and the daily weight gain $(\mathrm{DWG})$.

Blood was collected and the ovarian activity assessed every four days in the morning, before supplying the diet. The blood samples were removed by puncturing the jugular vein, using a glass tube with anti-coagulant to measure glucose and blood was collected in another tube without anti-coagulant to measure urea and cholesterol. The samples were then centrifuged at $1,000 \mathrm{x}$ g for 10 minutes and the plasma obtained was stored at $-20^{\circ} \mathrm{C}$. The blood concentrations of cholesterol, glucose and urea were determined in the EXAME Laboratory (Araguaína, TO) using enzymatic (cholesterol), oxidase/peroxidase (glucose) or urease (urea) methodologies. The plasmatic ureic nitrogen (PUN) was determined by multiplying the plasma urea by 0.466 that corresponded to $46.6 \%$ nitrogen in the urea molecule.

The ovarian activity was monitored by transrectum ultrasound, using a Honda HS $1500 \mathrm{~V}$ apparatus coupled to a frequency linear transductor adjustable to $5.0 ; 7.5$ or $10.0 \mathrm{MHz}$. The diameters were measured in millimeters $(\mathrm{mm})$ of the largest follicle present in each ovary.

The nutrient intake and daily weight gain data were analyzed statistically using the Statystical Analysis System (SAS, 2001) computer program. Regression analysis was 
Table 1 - Centesimal and bromatological composition of the experimental diets in $\% \mathrm{DM}$

\begin{tabular}{|c|c|c|c|c|}
\hline \multirow{2}{*}{ Itens } & \multicolumn{4}{|c|}{ Diets (\% urea) } \\
\hline & 0.00 & 0.44 & 0.88 & 1.32 \\
\hline Sorghum silage & 77.00 & 77.00 & 77.00 & 77.00 \\
\hline Soybean meal & 8.70 & 5.90 & 3.10 & 0.60 \\
\hline Ground corn & 13.60 & 15.90 & 18.30 & 20.30 \\
\hline Urea & 0.00 & 0.40 & 0.90 & 1.30 \\
\hline Ammonia sulfate & 0.00 & 0.05 & 0.09 & 0.14 \\
\hline \multirow[t]{2}{*}{ Mineral supplement* } & 0.64 & 0.64 & 0.64 & 0.64 \\
\hline & \multicolumn{4}{|c|}{ Composition (\% DM) } \\
\hline Dry matter & 48.40 & 48.40 & 48.50 & 48.30 \\
\hline Crude protein & 9.70 & 10.40 & 10.50 & 10.70 \\
\hline Neutral detergent fiber & 52.70 & 51.20 & 53.30 & 53.40 \\
\hline Acid detergent fiber & 27.70 & 27.90 & 27.60 & 27.60 \\
\hline Hemicellulose & 24.90 & 23.20 & 25.60 & 25.80 \\
\hline Ether extract & 1.90 & 2.00 & 2.10 & 2.00 \\
\hline Rumen degradable protein & 6.70 & 6.76 & 7.00 & 7.90 \\
\hline Rumen non-degradable protein & 2.40 & 3.64 & 3.50 & 2.80 \\
\hline
\end{tabular}

* Fospec-85. composition (in 1000 g): $\mathrm{Na}-140 \mathrm{~g} ; \mathrm{Ca}-151 \mathrm{~g} ; \mathrm{P}-85 \mathrm{~g}$; Mg - $10 \mathrm{~g}$; S - 15 g; Fe - 600 mg; Zn - $5200 \mathrm{mg}$; Cu - $1800 \mathrm{mg}$; Co - 200 mg; Mn - 1000 mg; I - 100 mg; Se - 27 mg; F - 740 mg

performed for all the variables assessed, with analysis of variance at the level of $5 \%$ significance.

The repeated measures of the blood parameters (PUN, glucose and cholesterol) and the follicular diameter taken over time from the same heifer were analyzed by the SAS ${ }^{\circledR}$ MIXED procedure (SAS, 2001), following the mixed linear model:

$\mathrm{y}_{\mathrm{ijk}}=\mu+\alpha_{\mathrm{i}}+\beta_{\mathrm{ij}}+\lambda_{\mathrm{k}}+(\alpha \gamma)_{\mathrm{ik}}+\varepsilon_{\mathrm{ijk}}$

where $\mathrm{y}_{\mathrm{ijk}}$ is a vector of the responses (PUN, glucose, cholesterol and follicular diameter) on day $\mathrm{k}$, measured on the $\mathrm{j}$-eth heifer in treatment $\mathrm{i} ; \mu$ is the general mean; $\alpha_{i}$ is the fixed effect of the treatment $i$, $\beta_{\mathrm{ij}}$ is the random effect of heifer $\mathrm{j}$ nested in treatment $\mathrm{i} ; \lambda_{\mathrm{k}}$ is the fixed effect of day $\mathrm{k} ; \alpha \gamma_{\mathrm{ik}}$ is the effect of the interaction between the treatment $\mathrm{i}$ and day $\mathrm{k}$; and $\varepsilon_{\mathrm{ijk}}$ is the random error.

Four covariance structures were used to model the repeated measurements (LITTELL et al., 1998). The structures that best fitted the data were chosen based on the smallest values of the Akaike and Bayesian Information Criteria. The PUN replicated data for glucose and follicular diameter were analyzed using random autoregression and covariance analysis and autoregression with adjusted means with symmetrical component, respectively.

\section{Results and discussion}

The DM intake, expressed in $\mathrm{kg}^{-1 a y^{-1}}$ and $\mathrm{g} \mathrm{kg}^{-1}$ $\mathrm{LW}^{0.75}$, presented quadratic responses to the increase in the urea levels in the diet $(p<0.05)$ while the intake in $\% \mathrm{LW}$ presented only a tendency to increase $(\mathrm{p}=0.064)$. Maximum intakes of $8.75 \mathrm{~kg}$ day $^{-1} 117.6 \mathrm{~kg} \mathrm{LW} \mathrm{LW}^{0.75}$ and $2.8 \% \mathrm{LW}$ were estimated, respectively, from the regression equations (TAB. 2), for the levels $0.7,0.6$ and $0.6 \%$ urea included in the diet.

The mean DM intakes in $\mathrm{kg}$ day estimated (7.6; $8.6 ; 8.6$ and 7.7) were greater than the value proposed by the NRC (2001) of $7.1 \mathrm{~kg}$ heifer ${ }^{-1}$ day $^{-1}$. DM intake is the most important nutritional factor to establish the quantities of nutrients available for health and animal production (NRC, 2001).

The high DM intake $\left(\mathrm{kg} \mathrm{day}^{-1}\right)$ obtained may have occurred because the heifers were raised exclusively on pasture and probably presented some type of nutritional restriction and presented a compensatory effect at the start of the experiment. Another fact that may also have contributed was that the NRC guidelines are based on taurine and not zebu animals to predict nutritional requirements and the foods used in the diet formulation have different nutrient levels due to the variations in temperature, moisture, luminosity and rainfall between temperate and tropical climates. 
Table 2 - Regression equations, coefficients of determination $\left(\mathrm{R}^{2}\right)$ and variation $(\mathrm{CV})$ and probability (p) for the intakes of dry matter (DM), crude protein (CP), neutral detergent fiber (NDF), acid detergent fiber (ADF), hemicelluloses (HEM) and ether extract (EE) in function of the urea levels in the diet

\begin{tabular}{|c|c|c|c|c|c|}
\hline \multirow{2}{*}{ Item } & \multirow{2}{*}{ Regression } & \multirow{2}{*}{$\mathrm{R}^{2}$} & \multirow{2}{*}{$\mathrm{CV} \%$} & \multicolumn{2}{|c|}{$\mathrm{p}$} \\
\hline & & & & Linear & Quadratic \\
\hline \multicolumn{6}{|c|}{$\mathrm{kg}$ day $^{-1}$} \\
\hline $\mathrm{DM}$ & $\hat{\mathrm{Y}}=7.5581+3.5297 \mathrm{X}_{\mathrm{ni}}-2.6169 \mathrm{X}_{\mathrm{ni}}^{2}$ & 0.197 & 13.587 & 0.049 & 0.044 \\
\hline $\mathrm{CP}$ & $\hat{Y}=0.7188+0.4317 X_{n i}-0.2837 X_{n i}^{2}$ & 0.249 & 14.101 & 0.023 & 0.036 \\
\hline NDF & $Y=4.2662$ & 0.152 & 13.232 & 0.082 & 0.103 \\
\hline $\mathrm{ADF}$ & $\hat{\mathrm{Y}}=2.1321+0.9996 \mathrm{X}_{\mathrm{ni}}-0.7166 \mathrm{X}_{\mathrm{ni}}^{2}$ & 0.191 & 13.488 & 0.049 & 0.049 \\
\hline HEM & $\mathrm{Y}=1.9598$ & 0.125 & 13.279 & 0.157 & 0.240 \\
\hline $\mathrm{EE}$ & $\hat{\mathrm{Y}}=0.1370+0.0876 \mathrm{X}_{\mathrm{ni}}-0.0618 \mathrm{X}_{\mathrm{ni}}{ }^{2}$ & 0.265 & 14.363 & 0.017 & 0.019 \\
\hline \multicolumn{6}{|c|}{$\mathrm{g} \mathrm{kg}^{-1} \mathrm{LW}^{0.75}$} \\
\hline $\mathrm{DM}$ & $\hat{\mathrm{Y}}=107.0925+32.9174 \mathrm{X}_{\mathrm{ni}}-25.7455 \mathrm{X}_{\mathrm{ni}}{ }^{2}$ & 0.202 & 9.668 & 0.060 & 0.043 \\
\hline $\mathrm{CP}$ & $\hat{Y}=10.1286+4.4383 X_{n i}-2.9101 X_{n i}^{2}$ & 0.266 & 10.160 & 0.018 & 0.029 \\
\hline NDF & $Y=50.7251$ & 0.120 & 9.665 & 0.123 & 0.141 \\
\hline $\mathrm{ADF}$ & $\hat{Y}=30.4347+9.3866 X_{n i}-7.03751 X_{n i}^{2}$ & 0.188 & 9.541 & 0.058 & 0.049 \\
\hline HEM & $Y=26.8622$ & 0.086 & 10.242 & 0.285 & 0.406 \\
\hline $\mathrm{EE}$ & $\hat{Y}=1.9252+0.9393 X_{n i}-0.67481 X_{n i}^{2}$ & 0.290 & 10.658 & 0.012 & 0.012 \\
\hline \multicolumn{6}{|c|}{$\% \mathrm{LW}$} \\
\hline $\mathrm{DM}$ & $\hat{\mathrm{Y}}=2.6318+0.5667 \mathrm{X}_{\mathrm{ni}}-0.4833 \mathrm{X}_{\mathrm{ni}}^{2}$ & 0.194 & 8.327 & 0.114 & 0.064 \\
\hline $\mathrm{CP}$ & $\hat{\mathrm{Y}}=0.2449+0.0945 \mathrm{X}_{\mathrm{ni}}-0.06201 \mathrm{X}_{\mathrm{ni}}^{2}$ & 0.257 & 9.251 & 0.020 & 0.033 \\
\hline NDF & $Y=1.4053$ & 0.101 & 9.186 & 0.165 & 0.163 \\
\hline $\mathrm{ADF}$ & $\hat{\mathrm{Y}}=0.7391+0.1894 \mathrm{X}_{\mathrm{ni}}-0.1460 \mathrm{X}_{\mathrm{ni}}{ }^{2}$ & 0.174 & 8.687 & 0.078 & 0.061 \\
\hline HEM & $Y=0.6435$ & 0.062 & 9.802 & 0.397 & 0.529 \\
\hline $\mathrm{EE}$ & $\hat{Y}=0.0486+0.0142 X_{n i}-0.0113 X_{n i}^{2}$ & 0.214 & 9.201 & 0.059 & 0.038 \\
\hline
\end{tabular}

$\hat{Y}$ : estimated value; $Y$ : mean; $X_{n i}$ : urea level

The reduction in DM intake from $8.8 \mathrm{~kg} \mathrm{day}^{-1}$ to $7.7 \mathrm{~kg}$ day $^{-1}$ observed starting at the 0.7 level to $1.32 \%$ urea in the total DM of the diet, may have occurred because of imbalance between RDP and energy in the diet, leading to a failure in synchromism between ammonia and energy in the rumen. The energy supply was probably lower than the availability of ammonia generated with the increase in urea in the diet starting at the $0.7 \%$ level. The main path for ammonia not used in the rumen is to cross the ruminal epithelium and reach the bloodstream. The possible excess of ammonia in the rumen generated by the increase in urea in the diet starting at the $0.7 \%$ level, consequently, raised the plasma ammonia concentration to a level close to that considered toxic (VISEK, 1984). According to the NRC (1996) the organism is stimulated to reduce diet intake because the ammonia concentration reaches the tissue tolerance limit and subsequent increases could lead to intoxication.
Rezende et al. (2008) observed quadratic performance in DM intake $(6.9 ; 7.3 ; 7.7 ; 7.3$ and $\left.6.9 \mathrm{~kg} \mathrm{day}^{-1}\right)$ when the urea levels $(0.0 ; 0.7 ; 1.4 ; 2.1$ and $2.8 \%$ on the total $\mathrm{DM}$ ) were raised in the diet by ruminal infusion, in increasing quantities $(2 ; 4 ; 6$ and 8$)$ of nitrogenated supplement consisting of ammonia, ammonia sulfate and casein at a ratio of 4.5:0.5:1.0. The casein represented protein substrate and especially energetic substrate due to the presence of branched chain fatty acids. The authors verified that the maximum DM intake $\left(7.7 \mathrm{~kg} \mathrm{day}^{-1}\right)$ was obtained with the $1.4 \%$ urea content in the diet, that was twice the urea level in the diet $(0.7 \%)$ found in the present study for the maximum DM intake. The justification for this fact may be in the energetic source used, because Rezende et al. (2008) used a protein containing fatty acids that probably made more energy available than the carbohydrate (starch) in the present study. 
Rennó et al. (2005) and Magalhães et al. (2006) supplied diets with 50:50 and 65:35 roughage:concentrate ratios, respectively, but with the same increasing urea levels $(0.0,0.65,1.30$ and $1.95 \%$ total DM in the diet) for feedlot crossbred steer and observed no effect of the urea on DM intake, with means of $8.97 \mathrm{~kg} \mathrm{day}^{-1}$ and $6.71 \mathrm{~kg}^{-1 a y}{ }^{-1}$ respectively. The fact that Magalhães et al. (2006) and Rennó et al. (2005) used urea levels up to $1.95 \%$ of the diet and did not observe reduction in DM intake, as verified in the present experiment with levels between 0.7 and $1.32 \%$ urea in the diet, was explained by the quantity of concentrate in the diets $(35 \%$ and $50 \% \times 23 \%)$, that were greater and may have made more energy available.

From the mean DM intakes estimated, a mean intake was detected of $0.0 \mathrm{~g}, 37.9 \mathrm{~g}, 76 \mathrm{~g}$ and $101.1 \mathrm{~g}$ urea heifer $^{-1}$ day $^{-1}$ respectively for the diets with $0.0,0.44,0.88$ and $1.32 \%$ urea. Considering the heifers initial weight $(277.9 \mathrm{~kg})$ and the known limit between 40 and $50 \mathrm{~g}$ urea $100 \mathrm{~kg}^{-1}$ LW (LOPES et al., 2000) none of the supposed intakes reached the limit of $139 \mathrm{~g}$ urea heifer ${ }^{-1}$ day $^{-1}$.

The diets in this experiment were formulated to be isoproteic with $14.1 \% \mathrm{CP}$ but the bromatological analysis showed that the CP levels were lower, 9.71; 10.40; 10.50 and $10.70 \% \mathrm{CP}$, respectively, for the diets with $0.0 ; 0.44$; 0.88 and $1.32 \%$ urea. This reduction was explained by the protein level of the sorghum silage that made up $77 \%$ of the diet as roughage. The protein content of the silage used in the formulation was $8.1 \% \mathrm{CP}$, while the silage supplied in the present study contained only $5.8 \% \mathrm{CP}$.

The CP intakes, expressed in $\mathrm{kg}$ day $^{-1}, \mathrm{~g} \mathrm{~kg}^{-1} \mathrm{LW}^{0.75}$ and $\% \mathrm{LW}$, performed quadratically with increase in urea in the diet $(\mathrm{p}<0.05)$. Maximum CP intakes were estimated from the regression equations (TAB. 2) of $0.88 \mathrm{~kg} \mathrm{day}^{-1}$, $11.82 \mathrm{~g} \mathrm{~kg}^{-1} \mathrm{LW}^{0.75}$ and $0.28 \% \mathrm{LW}$, for the level of $0.8 \%$ urea in the diet. As the CP contents in the diets were close and due to increase in DM intake resulting from the inclusion of urea, an increase in CP intake was expected.

The NRC (2001) recommended $0.887 \mathrm{~kg}$ day $^{-1}$ $\mathrm{CP}$ intake for this pre-puberty heifer category that was reached with the inclusion of $0.8 \%$ urea in the diet. It was estimated that the differences in the CP intakes $\left(\mathrm{kg} \mathrm{day}^{-1}\right)$ for the levels between 0.6 and $0.9 \%$ urea in the diet were small and biologically had no effect, so it was assumed that the $\mathrm{CP}$ intakes $\left(\mathrm{kg} \mathrm{day}^{-1}\right)$ met those recommended by the NRC (2001) with the inclusion of 0.6 and $0.9 \%$ urea in the total DM of the diet. However, from the diet

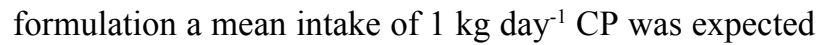
that was not supplied by the experimental diets. This fact must have been a consequence of the protein content of the silage used in the formulation with $8.1 \% \mathrm{CP}$, while the silage supplied in the present study contained only $5.8 \%$ $\mathrm{CP}$, reducing the protein level of the diets from $14 \%$ to
$9.71 ; 10.40 ; 10.50$ and $10.70 \% \mathrm{CP}$, respectively, for the levels of $0.0,0.44,0.88$ and $1.32 \%$ urea in the total DM.

Rennó et al. (2005) and Magalhães et al. (2006) worked with the same increasing urea levels $(0.0 ; 0.65$; 1.30 and $1.95 \%$ total DM) in isoprotein diets $(12 \% \mathrm{CP})$ for feedlot crossbred steer and did not observe a significant effect of including urea in the diet on the CP intake, with means of $0.85 \mathrm{~kg} \mathrm{day}^{-1}$ and $1.1 \mathrm{~kg} \mathrm{day}^{-1}$, respectively.

The NDF intakes, expressed in $\mathrm{kg}$ day ${ }^{-1}, \mathrm{~g} \mathrm{~kg}^{-1}$ $\mathrm{LW}^{0.75}$ and $\% \mathrm{LW}$ were not influenced by the urea levels in the diet $(\mathrm{p}<0.05)$ represented by the means $4.266 \mathrm{~kg}$ day $^{-1}, 58.725 \mathrm{~g} \mathrm{~kg}^{-1} \mathrm{PV}^{0.75}$ and 1.4\% PV (TAB. 2).

The mean NDF intake, estimated at $1.4 \% \mathrm{LW}$, was above the optimum NDF intake capacity that, according to Mertens (1992) is $1.2 \%$ LW. The excellent survival capacity of Zebus and their crossbreds probably contributed so that the NDF intake was above the optimum intake capacity, because of the better use of the roughage consumed (MENEZES; RESTLE, 2005).

The ADF intakes, expressed in $\mathrm{kg}$ day $^{-1}$ and $\mathrm{g} \mathrm{kg}^{-1} \mathrm{LW}^{0.75}$, presented a quadratic response to the increase in urea in the diet $(p<0.05)$ while the intake in $\% \mathrm{LW}$ presented tendency $(\mathrm{p}=0.064)(\mathrm{TAB} .2)$. The maximum intakes were $2.5 \mathrm{~kg} \mathrm{day}^{-1}, 33.56 \mathrm{~g} \mathrm{~kg}^{-1} \mathrm{LW}^{0.75}$ and $0.8 \% \mathrm{LW}$, obtained with the inclusion of $0.7 \%$ urea in the diet. The ADF intake also increased with increased DM intake.

The HEM intakes, expressed in $\mathrm{kg}$ day ${ }^{-1}, \mathrm{~g} \mathrm{~kg}^{-1}$ $\mathrm{LW}^{0.75}$ and $\% \mathrm{LW}$ were not influenced by the urea levels in the diet $(\mathrm{p}<0.05)$ with means of $1.9598 \mathrm{~kg} \mathrm{day}^{-1}, 26.8622$ $\mathrm{g} \mathrm{kg}^{-1} \mathrm{LW}^{0.75}$ and $0.6435 \%$ LW (TAB. 2).

The EE intakes, expressed in $\mathrm{kg}$ day ${ }^{-1}, \mathrm{~g} \mathrm{~kg}^{-1} \mathrm{LW}^{0.75}$ and $\% \mathrm{LW}$, presented quadratic response to the increase in the urea level in the diet $(p<0.05)$. Maximum intakes were estimated from the regression equations of $0.17 \mathrm{~kg} \mathrm{day}^{-1}$, $2.25 \mathrm{~g} \mathrm{~kg}^{-1} \mathrm{LW}^{0.75}$ and $0.053 \% \mathrm{LW}$, for the $0.7 \%$ level of urea included in the diet (TAB. 2). The EE intakes followed the same tendency as the DM intakes and although differences were observed in the intakes among the diets, they could be considered biologically insignificant.

The PUN concentration was influenced by the urea (U) level in the diet $(\mathrm{p}<0.05)$, the collection day (D) $(\mathrm{p}<0.05)$ and the U x D interaction $(\mathrm{p}<0.05)$ (TAB. 3). The $0.6 \%$ urea level in the diet was the critical point for the maximum PUN concentration, PUN $10.96 \mathrm{mg} \mathrm{dL}^{-1}$, on the $40^{\text {th }}$ day.

When the level of urea in the diet was raised above $0.6 \%$ to reach $1.32 \%$, a progressive reduction was observed in the PUN concentration that was probably due to the reduction in DM intake observed from the $0.7 \%$ to 
Table 3 - Regression equations, coefficients of determination $\left(\mathrm{R}^{2}\right)$ and of variation $(\mathrm{CV})$ and probability (p) of the variables plasmatic ureic nitrogen (PUN), plasma glucose, total plasma cholesterol and diameter of the largest follicle in function of the urea (U) levels in the diet and day (D) observed

\begin{tabular}{|c|c|c|c|c|c|c|}
\hline \multirow{2}{*}{ Variable } & \multirow{2}{*}{ Regression } & \multirow{2}{*}{$\mathrm{R}^{2}$} & \multirow{2}{*}{$\mathrm{CV} \%$} & \multicolumn{3}{|c|}{$\mathrm{p}$} \\
\hline & & & & Linear & Quadratic & Urea*Day \\
\hline PUN ( $\left.\mathrm{mg} \mathrm{dL}^{-1}\right)$ & $\begin{array}{c}\hat{Y}=80.156+5.030 U+0.064 \\
-0.113 \mathrm{DU}\end{array}$ & 0.900 & 25.420 & 0.014 & 0.9130 & 0.0003 \\
\hline Plasma glucose $(\mathrm{mg} / \mathrm{dL})$ & $\begin{aligned} \hat{\mathrm{Y}}= & 80.374-21.790 \mathrm{U}+1.090 \mathrm{D} \\
& +12.330 \mathrm{U}^{2}-0.024 \mathrm{D}^{2}\end{aligned}$ & 0.101 & 21.052 & 0.002 & 0.0040 & 0.5650 \\
\hline $\begin{array}{l}\text { Total plasma cholesterol } \\
\left.(\mathrm{mg} \mathrm{dL})^{-1}\right)\end{array}$ & $Y=119.39$ & 0.210 & 32.376 & 0.006 & $<0.0001$ & 0.9120 \\
\hline $\begin{array}{l}\text { Diameter }(\mathrm{mm}) \text { largest } \\
\text { follicle }\end{array}$ & $\begin{array}{c}\hat{\mathrm{Y}}=7.287+2.39 \mathrm{U}+0.2 \mathrm{D}- \\
2.005 \mathrm{U}^{2}+0.002 \mathrm{DU}-0.003 \mathrm{D}^{2}\end{array}$ & 0.055 & 23.764 & 0.820 & 0.0020 & 0.9510 \\
\hline
\end{tabular}

$\hat{Y}$ : estimated value; Y: mean

the $1.32 \%$ level of urea in the diet. The increasing linear performance of the PUN concentrations observed in the heifers that received the diets containing 0.0 and $0.4 \%$ urea was explained by the increase in the DM intake verified up to the $0.7 \%$ level of urea in the diet. The decreasing linear performance of the PUN concentrations observed in the heifers that received the diet containing 0.88 and $1.32 \%$ urea was justified by the reduction in DM intake observed for the levels starting at $0.7 \%$ urea in the diet.

Several factors probably contributed so that the maximum PUN concentration obtained at the critical point was $10.96 \mathrm{mg} \mathrm{dL}^{-1}$. First, the protein content of the diets was lower than the minimum suggested by the NRC (2001) for this animal category $(12 \% \mathrm{CP})$. Second, these heifers could ingest up to $139 \mathrm{~g}$ urea/day but the diets with $0.0,0.44,0.88$ and $1.32 \%$ urea resulted in mean intakes of $0.0 \mathrm{~g}, 37.85 \mathrm{~g}$, $76 \mathrm{~g}$ and $101.08 \mathrm{~g}$ urea/heifer/day, respectively, that were lower. The daily CP intake, according to the NRC (2001) for this animal category is $0.887 \mathrm{~kg} \mathrm{day}^{-1}$ and was supplied by the diets that had 0.6 to $0.9 \%$ urea included. Based on these data, it was concluded that the PUN concentrations obtained in this experiment could not reach levels equal to $16 \mathrm{mg} \mathrm{dL}^{-1}$ or more.

Starting on the $50^{\text {th }}$ day the PUN concentrations for all the urea levels in the diet should have stabilized close to $10.96 \mathrm{mg} \mathrm{L}^{-1}$ which was not observed because the experiment finished on the $50^{\text {th }}$ day. The probable explanation for the PUN stabilization at concentrations close to $10.96 \mathrm{mg} \mathrm{L}^{-1}$ was that to generate this concentration, the quantity of diet consumed should have provided balanced ammonia and energy, reaching first a stable DM intake and consequently stable PUN concentrations.

The plasma glucose concentration was influenced by the urea $(U)$ level in the diet $(p<0.05)$ and by the collection day (D) $(\mathrm{p}<0.05)(\mathrm{TAB} 3)$. The $0.77 \%$ urea level in the diet was the critical point for the maximum plasma glucose concentration of $84.97 \mathrm{mg} \mathrm{dL}^{-1}$ on the $24^{\text {th }}$ day.

The glucose plasma concentrations detected in the present study were greater than the values obtained by Pogliani and Birgel Júnior (2007), who examined serum and plasma samples from 413 healthy Holstein cattle and reported concentrations from $64.0 \mathrm{mg} \mathrm{dL}^{-1}$ to $76.1 \mathrm{mg} \mathrm{dL}^{-1}$ for three to 24 month-old animals.

The high plasma glucose concentrations obtained in the present study may have been related to the high DM intake presented by the heifers. It was estimated that the DM intake was superior by $0.458 \mathrm{~kg}$ day $^{-1}, 1.504 \mathrm{~kg}$ day $^{-1}, 1.538 \mathrm{~kg}$ day $^{-1}$ and $0.557 \mathrm{~kg}^{-1} \mathrm{day}^{-1}$ to the $7.1 \mathrm{~kg}^{-1 a y^{-1}}$ recommended by the NRC (2001), respectively, for the diets with $0.0,0.44,0.88$ and $1.32 \%$ urea in the total DM of the diet. This probably increased the nutrient input and contributed to raising the plasma glucose level. Another factor that may also have contributed was that the females were pre-puberty heifers and did not require glucose for milk production.

High PUN concentrations can alter the energetic balance and the plasma glucose concentration. Conversion of ammonia to urea in the liver is an energetic cost and when the quantity of ammonia in the blood is greater, the energetic expenditure and quantity of urea produced is also greater. PUN concentrations of $16 \mathrm{mg} \mathrm{dL}^{-1}$ reported by Staples et al. (1993), quoted by Butler (1998), or $19 \mathrm{mg} \mathrm{dL}^{-1}$ (BUTLER, 1998) can cause energetic deficit and influence fertility. As the PUN concentrations detected in the heifers in the present study remained below these concentrations, the energetic condition and the plasma glucose levels were probably not influenced. 
The means estimated for DM intake were close in value $\left(7.558 \mathrm{~kg} \mathrm{day}^{-1}\right.$ and $7.657 \mathrm{~kg} \mathrm{day}^{-1}$, respectively) among the 0.0 and $1.32 \%$ urea levels in the diet, and also between the levels 0.44 and $0.88 \%\left(8.604 \mathrm{~kg}\right.$ day $^{-1}$ and $8.637 \mathrm{~kg}^{-1} \mathrm{yy}^{-1}$ respectively). This proximity in DM intake values might have contributed to generating glucose quantities that were also close among these diets. This could justify the similar performance of the plasma glucose concentrations among the diets containing 0.0 and $1.32 \%$ urea and also among the diets with 0.44 and $0.88 \%$ urea of the total DM.

Although the mean DM intake was smaller $\left.(7.558 \mathrm{~kg} \mathrm{day})^{-1}\right)$ for the heifers that ingested the diet with $0.0 \%$ urea in the total DM, the plasma glucose concentrations obtained in these heifers were the greatest. As these heifers received $0.0 \%$ urea in the diet and also presented low PUN levels, it was assumed that the energetic expense to convert ammonia into urea in the liver was less, because of the small quantity of PUN produced. This fact may justify the higher plasma glucose levels in these animals.

The total plasma cholesterol concentrations were not influenced by the urea levels in the diets $(p<0.05)$ and presented a mean of $119.39 \mathrm{mg} \mathrm{dL}^{-1}$ (TAB. 3). This was probably because of the low protein content of the diets and also the low PUN concentrations.

The total cholesterol plasma concentrations detected in the present study were greater than the values obtained by Pogliani and Birgel Júnior (2007), who examined 413 healthy Holstein cattle and found concentrations from $86.4 \mathrm{mg} \mathrm{dL}^{-1}$ to $105 \mathrm{mg} \mathrm{dL}^{-1}$ for 12 to 24 month-old heifers. The high total plasma cholesterol levels obtained in the present study were also explained by the high DM intake that increased the nutrient input and contributed to raising lipogenesis.

Borges et al. (2001b) reported a mean total plasma cholesterol concentration of $85.9 \mathrm{mg} \mathrm{dL}^{-1}$ during the normal oestrus cycle in crossbred heifers (Holstein $\mathrm{x}$ Zebu) in a feedlot, fed with coast grass hay, concentrate and mineral mixture ad libertum. The mean total cholesterol concentration (119.39 $\left.\mathrm{mg} \mathrm{dL}^{-1}\right)$ obtained in the present study was greater, probably because these heifers presented high DM intake that increased the nutrient input and might have raised glucose synthesis and lipogenesis.

The diameter of the largest follicle tended to be influenced by the urea (U) level in the diet $(\mathrm{p}=0.09)$ and the collection day (D) $(\mathrm{p}=0.08)(\mathrm{TAB} .3)$. The $0.6 \%$ urea level in the diet was the critical point to obtain the maximum follicular diameter of $11.08 \mathrm{~mm}$ on the $31^{\text {st }}$ day and there was a progressive fall with subsequent increases in the urea level in the diet.
In a comparative study with females that presented two waves of follicular growth, diameters were observed of 17.1 and $16.5 \mathrm{~mm}$ for dominant follicles from taurine females (GINTHER et al., 1989) and 11.3 and $12.1 \mathrm{~mm}$ for the dominant follicles from Zebu females (FIGUEIREDO et al., 1997). From these reports, Baruselli et al. (2007) suggested that female zebus might present smaller diameter of the dominant follicle than the taurine females. Borges et al. (2003) observed that the ovulatory follicle diameter in Nellore cows presented a mean of $11.0 \pm 0.9 \mathrm{~mm}$ and in Gir cows the mean was $13.0 \pm 1.7 \mathrm{~mm}$. As the females assessed in the present study were crossbred heifers entering puberty and were yet to reach sexual maturity, it was acceptable that they presented smaller follicular diameter.

It was observed that the diameter of the greatest follicle measured in the heifers submitted to the four diets reached the size necessary to acquire ovulation capacity that is from $8 \mathrm{~mm}$ when they begin to develop more $\mathrm{LH}$ receptors (DRIANCOURT, 2000).

Ammonia and urea at high plasma concentration, according to the NRC (2001), can damage the growth and development of the ovarian follicle and its oocyte, that probably did not occur in the present experiment because the PUN concentrations were low and remained below $16 \mathrm{mg} \mathrm{dL}^{-1}$. Another fact that must have contributed was the favorable energetic condition of these heifers, because they presented high plasma glucose and cholesterol concentrations.

The maximum follicular diameter performed similarly during the experiment among the heifers that received the diets containing 0.44 and $0.88 \%$ urea and also among the heifers fed the diets containing 0.0 and $1.32 \%$ urea. This fact may have been the result of the proximity of the values estimated for DM intake $(\mathrm{kg}$ day $\left.^{-1}\right), \mathrm{CP}$ intake $\left(\mathrm{kg} \mathrm{day}{ }^{-1}\right)$ and plasma glucose levels observed among the animals fed the diets containing 0.44 and $0.88 \%$ urea and also for those that received the diets containing 0.0 and $1.32 \%$ urea.

Dawuda et al. (2004) did not detect significant difference $(\mathrm{p}<0.05)$ among the maximum follicular diameters (26.4 mm x $28.3 \mathrm{~mm}$, respectively) in cows fed diet containing $17.5 \% \mathrm{CP}$ and $11.8 \mathrm{MJ} \mathrm{kgMS}^{-1} \mathrm{EM}$ (control diet) or that received the same diet with the addition of $250 \mathrm{~g}^{\mathrm{g} e a} \mathrm{cow}^{-1} \mathrm{day}^{-1}$. Urea did not influence the maximum follicular diameter probably because the energetic availability of the diet and the quantity of urea included in the diet must have been compatible because there was no reduction in DM intake of $20.9 \mathrm{~kg} \mathrm{day}^{-1}$ or $20.4 \mathrm{~kg} \mathrm{day}^{-1}$ respectively. In the present experiment, the heifers that received the diet with $1.32 \%$ urea tended to present the smallest follicular diameters in spite of the 
lower urea intake estimated at $101.08 \mathrm{~g} \mathrm{day}^{-1}$ possibly because of the decrease in DM intake indicating imbalance between energy supply and ammonia in the rumen.

Garcia-Bojalil et al. (1998b) increased the supply of RDP from 11.1 to $15.7 \%$ in the DM of diets supplied to Holstein cows in the first 120 days post partum and verified reduction in the greatest follicular diameter from $24.8 \mathrm{~mm}$ to $18.9 \mathrm{~mm}$ and in the insulin concentration from 0.69 to $0.55 \mathrm{mg} \mathrm{dL}^{-1}$. Based on the low insulin concentration, the authors suggested that the cows fed diet containing $15.7 \%$ RDP were less efficient in using energy for follicular growth probably because of the greater energetic expense to convert more ammonia to urea. This was contrary to that observed in the present study, because the RDP levels in the diets were lower than the values used by these authors.

The DWG was not altered in function of the levels of urea included in the diets $(p<0.05)$, with means of $1.66 \mathrm{~kg} \mathrm{day}^{-1}$. The estimated means for the DWG of $1.550,1.734,1.753$ and $1.603 \mathrm{~kg} \mathrm{day}^{-1}$, respectively, for the $0.0 ; 0.44 ; 0.88$ and $1.32 \%$ urea levels in the diets were higher than the values proposed by the NRC (2001) of $0.75 \mathrm{~kg} \mathrm{day}^{-1}$. This was probably because these heifers were raised exclusively on pasture and when placed in the feedlot had access to diet superior in quantity and quality that made more nutrients available than their organisms were used to and allowed compensatory weight gain.

Pre-puberty heifers submitted to diets that take the RDP higher than $0.9 \mathrm{~kg} \mathrm{day}^{-1}$ tended to accumulate adipose tissue on the udder and presented hormone alterations that damaged the mammary gland development and future milk production (CAMPOS et al. 2005). Fat accumulation in the pelvic region can interfere in blood supply to the ovary and uterus, and in oocyte capture, affecting the fertility of these females (SILVEIRA; DOMINGUES, 1995).

\section{Conclusion}

Urea can be added to the $1.32 \%$ level on the total $\mathrm{DM}$ of the diet, without affecting daily weight gain or follicle growth in crossbred heifers.

\section{References}

BARUSELLI, P. S.; GIMENES, L. U.; SALES, J. N. S. Fisiologia reprodutiva de fêmeas taurinas e zebuínas. Revista Brasileira de Reprodução Animal, v. 31, n. 02, p. 205-211, 2007.

BOLAND, M. P.; LONERGAN, P.; O'CALlAGHAN, D. Effect of nutrition on endocrine parameters, ovarian physiology, and oocyte and embryo development. Theriogenology, v. 55, n. 06, p. 1323-1340, 2001.

BORGES, A. M. et al. Concentrações plasmáticas de colesterol total e lipoproteínas de alta densidade em novilhas mestiças doadoras de embriões tratadas com somatotropina bovina recombinante. Arquivo Brasileiro de Medicina Veterinária e Zootecnia, v. 53, n. 05, p. 605-610, 2001 b.

BORGES, A. M. et al. Desenvolvimento luteal e concentrações plasmáticas de progesterona em vacas das raças Gir e Nelore. Revista Brasileira de Zootecnia, v. 32, n. 02, p. 276-283, 2003.

BUTLER, W. R. Effect of protein nutrition on ovarian and uterine physiology in dairy cattle. Journal of Dairy Science, v. 81, n. 09 , p. 2533-2539, 1998.

CAMPOS, O. F. et al. Recria de bovinos leiteiros. Juiz de Fora: Embrapa Gado de Leite, 2005. 8 p. (Circular técnico, 84).

DAWUDA, P. M. et al. The effect of a diet containing excess quickly degradable nitrogen (QDN) on reproductive and metabolic hormonal profiles of lactating dairy cows. Animal Reproduction Science, v. 81, n. 03/04. p. 195-208, 2004.

DISKIN, M. G. et al. Effects of nutrition and metabolic status on circulating hormones and ovarian follicle development in cattle. Animal Reproduction Science, v. 78, n. $03 / 04$, p. $345-370,2003$.

DRIANCOURT, M. A. Regulation of ovarian follicular dynamics in farm animals implications for manipulation of reproduction. Theriogenology, v. 55, n. 06, p. 1211-1239, 2001.

FIGUEIREDO, R. A. et al. Ovarian follicular dynamics in nelore breed (Bos indicus) cattle. Theriogenology, v. 47, n. 08, p. 1489-1505, 1997.

GARCIA-BOJALIL, C. M. et al. Protein degradability and calcium salts of long-chain fatty acids in the diets of lactating dairy cows: reproductive responses. Journal of Dairy Science, v. 81, n. 05, p. 1385-1395, 1998b.

GINTHER, O. J.; KNOPF, L.; KASTELIC, J. P. Temporal associations among ovarian events in cattle uring oestrous cycles with two and three follicular waves. Journal of Reproduction and Fertility, v. 87, p. 223-230, 1989.

LITTELL, R. C.; HENRY, P. R.; AMMERMAN, C. B. Statistical analysis of repeated meansures data using SAS procedures. Journal Animal Science, v. 76, n. 04, p. 12161231, 1998.

LOPES, H. O. S. et al. Recomendações técnicas para a utilização da uréia pecuária na alimentação animal. Planaltina: Embrapa cerrados, 2000. 35 p. (Circular técnico, 8)

MAGALHÃES, K. A. et al. Performance, digestibility and carcass characteristics of feedlot dairy steers fed diets with different urea levels. Arquivo Brasileiro de Medicina Veterinária e Zootecnia, v. 58, n. 05, p. 860-867, 2006.

MENEZES, L. F. G.; RESTLE, J. Desempenho de novilhos de gerações avançadas do cruzamento alternado entre as Raças Charolês e Nelore, terminados em confinamento. Revista Brasileira de Zootecnia, v. 34, n. 06, p. 1927-1937, 2005. 
MERTENS, D. R. Análise da fibra e sua utilização na avaliação de alimentos e formulação de rações. In: SIMPÓSIO INTERNACIONAL DE RUMINANTES, 1992. Lavras, Anais... Lavras: SBZ-ESAL, 1992. p. 188.

NATIONAL RESEARCH COUNCIL - NRC. Nutrient requirements of beef cattle. 7. ed. Washington, D.C.: National Academic of Sciences, 1996.

NATIONAL RESEARCH COUNCIL - NRC. Nutrient requeriments of dairy cattle. 7. ed. Washington, D. C.: National Academic of Sciences, 2001.

POGLIANI, F. C.; BIRGEL JÚNIOR, E. Valores de referência do lipidograma de bovinos da raça holandesa, criados no Estado de São Paulo. Brazilian Journal of Veterinary Research and Animal Science, v. 44, n. 05, p. 373-383, 2007.

RENNÓ, L. N. et al. Níveis de uréia na ração de novilhos de quatro grupos genéticos: consumo e digestibilidades totais. Revista Brasileira de Zootecnia, v. 34, n. 05, p. 1775-1785, 2005.

REZENDE, L. H. G. S. et al. Consumo e digestibilidade do feno de capim-braquiária em bovinos de corte sob suplementação com mistura contendo sulfato de amônia, caseína e uréia. Revista Brasileira de Zootecnia, v. 37, n. 04, p. 717-723, 2008.
STATISTICAL ANALYSES SYSTEM (SAS). User's Guide Statistics. Cary, N.C.: SAS Institute, 2001.

SILVA, D. J.; QUEIROZ, A. C. Análise de alimentos: Métodos químicos e biológicos. 3. ed. Universidade Federal de Viçosa, 2002.

SILVEIRA, A.C.; DOMINGUES, C. A.C. Sistema de alimentação de novilhas em crescimento. In: PEIXOTO, A. M.; MOURA, J. C.; FARIA, V. P. (Ed.). Nutrição de bovinos: conceitos básicos e aplicados. Piracicaba: FEALQ, 1995. p.95-117.

STAPLES, C. R. et al. Protein intake and reproductive performance of dairy cows: a review, a suggested mechanism, and blood and milk urea measurements. In: Proc. 4th Annu. Florida Ruminant Nutr. Symp., Univ. Florida,Gainesville, p. 37-51, 1993.

VAN SOEST, P. J.; ROBERTSON, J. B.; LEWIS, B. A. Symposium: carbohydrate metodology, metabolism, and nutritional implications in dairy cattle. Journal of Dairy Science, v. 74, n. 10, p. 3583-3597, 1991.

VISEK, W. J. Ammonia: Its effects on biological systems, metabolic hormones, and reproduction. Journal of Dairy Science, v. 67, n. 03, p. 481-498, 1984. 